DOI 10.37882/2223-2982.2020.07.14

\title{
«ЯЗЫКУ ФРАНЦУЗСКОМУ БЫЛА ПРЕОТЛИЧНО ОБУЧЕНА»: ИМПЕРАТРИЦА ЕЛИЗАВЕТА ПЕТРОВНА - НАЧАЛО ЭПОХИ ГАЛЛОМАНИИ В РОССИИ
}

\section{"WAS TAUGHT THE FRENCH LANGUAGE VERY WELL": EMPRESS ELIZABETH PETROVNA - THE BEGINNING OF THE ERA OF GALLOMANIA IN RUSSIA}

\section{A. Kolobkova}

Summary: The article examines the origins of such a widespread social and cultural phenomenon as gallomania in Russia in the XVIII-XIX centuries. This term is used to refer to the widespread fascination of the noble class with everything French - language, literature, culture, fashion, music, theater. In historical science, the beginning of gallomania is associated with the reign of Elizabeth Petrovna, the daughter of Peter I. The Future Empress learned French at the age of 11-12, and read a lot in French. The article discusses the specifics of home education and training Elizabeth Petrovna received, reveals the aspects of home training of tsarevna Elizabeth in French by Isaac Pavlovich Veselovsky - a teacher whose pedagogical service influenced the lifestyle of representatives of subsequent generations of the highest society in Russia. The author explores the reasons for the passion for everything French, lists the signs of increasing gallomania during the reign of Elizabeth Petrovna.

Keywords: gallomania, Francophonie, Empress Elizabeth Petrovna, Isaac Pavlovich Veselovsky, learning French, home schooling.
$\mathrm{X}$ арактерным явлением общественной и культурной жизни России XVIII века, повлиявшим и на образовательную среду, стала галломания - увлечение всем французским, преклонение перед французским образом жизни. Появление этого феномена относится ко времени правления императрицы Елизаветы (1741-1761), а причины объясняются ее воспитанием и обучением.

Елизавета Петровна - дочь императора Петра Великого, родилась 18 декабря (по старому стилю) 1709 года в селе Коломенском. Отец был довольно обрадован рождению дочери, хотя заниматься воспитанием и просто находиться в кругу семьи ему приходилось довольно редко. Очень рано, буквально с трех лет, Елизавету стали учить немецкому языку [1, с. 7]. Девочка достигла таких успехов, что сделала немецкий языком домашнего обихода: общалась на нем со своей семьей. «Царевна Елизобет Петровна больше гаварит по-немецки, нежели по-русски», - писала любимая сестра Петра I царевна Наталья Алексеевна в одном из своих писем [1, с. 8].

\author{
Колобкова Анастасия Анатольевна \\ К.п.н., дочент, АНОО ВО Центросоюза РФ «Российский \\ университет кооперации», г. Мытищи \\ akolobkova@yandex.ru
}

Аннотация: В статье рассматриваются истоки такого распространенного В России XVIII-XIX ВB. общественного и культурного явления, как галломания. Этим термином принято называть повсеместное увлечение персон дворянского сословия всем французским - языком, литературой, культурой, модой, музыкой, театром. В исторической науке начало галломании связывают со временем правления Елизаветы Петровны, дочери Петра І. Будущая императрица выучила французский язык в 11-12 лет, много читала по-французски. В статье рассматриваются особенности домашнего воспитания и обучения Елизаветы Петровны, раскрываются аспекты домашнего обучения цесаревны Елизаветы французскому языку Исааком Павловичем Веселовскимучителем, педагогическое служение которого повлияло на образ жизни представителей последующих поколений высшего света российского общества. Исследуются причины увлечения всем французским, перечисляются приметы нарастающей галломании в период правления Елизаветы Петровны.

Ключевые слова: галломания, франкофония, императрица Елизавета Петровна, Исаак Павлович Веселовский, изучение французского языка, домашнее обучение.

Французский же язык цесаревна Елизавета выучила только к 11-12 годам. Родители очень рассчитывали, что кто-нибудь из их дочерей породнит дом Романовых с фамилией Бурбонов, а маленькая Лиза станет невестой Людовика XV, в этой связи призвали для домашнего обучения девочек французскому языку полиглота, дипломата, незаурядного человека, и как оказалось, результативного учителя, привившего любовь ко всему французскому у будущей императрицы - Исаака Павловича Веселовского (1690-1754).

Родился Исаак Павлович в Москве. В гимназии пастора Эрнста Глюка, куда Исаак поступил вслед за своим старшим братом Авраамом, он слыл не самым прилежным учеником, к тому же еще и озорником [3], но уже в те годы отличился феноменальной способностью к иностранным языкам, смышленостью, остроумием, а его оригинальные остроты и каламбуры мгновенно становились популярными.

Как и его братья, Исаак Павлович отлично овладел 
несколькими иностранными языками, именно поэтому его дипломатическая карьера была предрешена, в 1707 году он поступает на службу в Посольский приказ, где получает должность переводчика с немецкого и латинского [4, с. 97]. Способности молодого дипломата очень быстро были справедливо оценены, уже в 1709 году Исаак Павлович был направлен для службы в российское посольство в Пруссии, а в 1710 году - в Дании [5].

Опыт и обширные знания И.П. Веселовского, приобретенные во время службы в названных странах, были высоко оценены самим Петром І, дипломат сопровождал его во время путешествия по Европе в 1716-1717 гг., в ходе которого русский царь хотел заключить военный союз с Пруссией и Данией против Швеции [3]. Помимо этого, Петр Великий восхищался тем, насколько виртуозно владел Веселовский французским языком. Во время пребывания Петра I в Париже, когда Петр держал на руках маленького мальчика - короля Людовика $\mathrm{XV}$, ровесника дочери, царевны Елизаветы, когда, смеем предположить, и мелькнула мысль Петра Алексеевича о возможности породниться с французским монархом, именно Исаак Павлович был при Петре переводчиком с французского, что и послужило впоследствии выбору Российского государя назначить Веселовского быть домашним учителем французского для дочерей Анны и Елизаветы.

Исаак Веселовский был близок с А.Д. Меншиковым и с самим Петром I, и карьера Исаака Павловича после европейского путешествия царя взметнулась на новую высоту: с 1718 г. он секретарь и одновременно глава Иностранной экспедиции Посольской канцелярии, а с февраля 1720 г. - секретарь всей Коллегии иностранных дел [3]. Однако, когда один из братьев Веселовских, Авраам, попал в опалу, Веселовский Исаак был сразу переведен в менее престижную Берг-коллегию. Но там Исаак Павлович долго не пробыл: Петр I вспомнил о лингвистическом даровании бывшего дипломата и доверил именно ему домашнее обучение своих дочерей Анны и Елизаветы французскому языку. Как мы уже говорили выше, император Петр Великий желал, чтобы его дочь стала женой французского короля, поэтому он считал чрезвычайно важным знание французского языка в высокой степени.

В течение трех лет с июня 1722 по июнь 1725 гг. юная цесаревна с помощью своего учителя Исаака Веселовского приобщалась к французской словесности и культуре [3]. Превосходно выучив язык, Елизавета Петровна пристрастилась к чтению французских книг, причем читала она не только художественную литературу, но и книги по философии, истории, политике. Об этом свидетельствует опубликованный в 1895 г. в седьмом томе «Материалов для истории императорской Академии наук» [5, с. 332-339] каталог французской литературы, которая принадлежала Елизавете Петровне. Список этот опровергает расхожие представления о Елизавете как «веселой царице», капризной и изнеженной любительнице развлечений и праздников. Каталог французских изданий свидетельствует о том, что императрица очень интересовалась политической историей различных европейских стран. К 1745 г., по сведениям В.К. Тредиаковского, в каталоге было уже 583 издания [1, с. 9].

Во времена правления предшественницы Елизаветы, Анны Иоанновны, в России «безраздельно господствовали немцы», и это вызывало повсеместное народное неодобрение. Как свидетельствует историк С.М. Соловьев, чувства русских людей оскорбляло то, что фаворитом императрицы был иностранец, первый кабинет-министр - также иностранец. Иностранцами были двое действующих фельдмаршалов, а также президенты коллегий [6, с. 636]. Елизавета Петровна положила конец засилью немцев в управлении. Она руководствовалась принципом своего отца: иностранные специалисты использовались как профессионалы, но важнейшие государственные должности занимали только русские.

Вместе с уменьшением влияния немцев падает и престиж немецкого языка. В моду входит французский язык. Во время правления Елизаветы резко вырос интерес ко всему французскому. Предпочтения дворян можно проследить по выбору учебных дисциплин в Шляхетском корпусе. По данным, приведенным С.В. Девятовой и В.И. Купцовым, в 1733 г. французский язык стал третьим по популярности предметом (после немецкого языка и танцев), выбранным студентами (на его изучение подписался 51 учащийся) $[7$, с. 8].

Принято говорить о том, что во время правления Елизаветы Петровны начался период галломании в России, пик которого пришелся на вторую половину XVIII - первую треть XIX в. Термин «галломания» Т.Ю. Загрязкина определяет как «интенсивное проникновение французского языка и культуры в русский ареал, восприятие и переработка этого влияния» [9, с. 29]. Действительно, французская культура быстро проникает во все сферы жизни дворянского общества, российской аристократии. На французском языке общаются в светских салонах, его изучают при помощи домашних учителей, гувернеров, и в учебных заведениях, на французском языке пишутся художественные произведения, огромное количество галлицизмов входит в русский литературный язык. Хорошим тоном стало иметь дома книги на французском языке. Известные русские просветители М.В. Ломоносов и В.С. Тредиаковский много переводят с французского языка. Французская книга в России начинает занимать 3-е место по количеству изданий, уступив только книгам на латинском и немецком языках [9, с. 34]. 
Знание французского языка для любого образованного человека становится обязательным, и это объясняется несколькими причинами. Конечно, прежде всего здесь определяющую роль сыграло приоритетное экономическое, культурное и политическое положение Франции в Европе [Кол]. Во-вторых, французский язык был высоко развитым языком, который был «нормализован» (аспекты языкознания) значительно раньше, чем другие европейские языки. Так называемый «образцовый язык» (le bon usage) уже в XVII в. использовался в сфере светской жизни, а также как язык науки и образования [9, с. 35]. Французский двор был образцом для подражания во всех странах Европы. Соответственно, своеобразным «образцом» постепенно становится и французский язык.

Отметим, что французский язык и культура во время правления Елизаветы Петровны проникали в Россию не только через книги, но и через носителей этого языка. В Россию все чаще стали въезжать деятели культуры, писатели, дипломаты, военные, аристократы и представители низших слоев, которые, в первую очередь конечно же, пытались найти в России заработок.

Необходимо сказать, что уже в тот исторический момент французы в какой-то степени начали играть значимую роль и в Российской политике. Так, большую роль в восхождении Елизаветы на трон сыграл французский посланник маркиз де ла Шетарди [9, с. 39]. Помогая Елизавете, Шетарди надеялся, что внешняя политика России станет более благоприятной для Франции. Елизавета действительно испытывала симпатию к Людовику XV, питала слабость ко всему французскому. Первое время Шетарди входил в число наиболее близких к императрице людей. В «Энциклопедическом словаре» Ф.А. Брокгауза и И.А. Ефрона Шетарди характеризуется как «великосветский француз», который обладал живым умом, любил блистать в высшем обществе и мог преподавать «уроки высшего этикета и утонченного изящества» [10, с. 537]. Однако его интриги против канцлера А.П. Бестужева, его навязчивость и стремление управлять волей императрицы вызвали сильное недовольство Елизаветы, и, в конце концов, француз был выслан на родину [11, с. 58].

Наступает целая эпоха, когда приезжие небогатые французы, в поисках лучшей жизни в России, становились гувернерами - домашними учителями французского языка. Если в университетах по-прежнему важная роль отводилась латыни и немецкому языку, то домашнее образование было преимущественно французским, когда обучали не только французскому языку, но и - на французском. Спрос на французов - учителей возрастал, и зачастую намного превышал предложение, в этой связи нередко должность гувернера, учителя французского занимал человек без всякой профессиональной подготовки [12, с. 33]. Конечно, существовал указ, предписывавший всем желающим заниматься преподаванием языка пройти аттестацию в Петербургской Академии наук либо в Московском университете. Однако далеко не все являлись на эту аттестацию. В любом случае французский язык моментально открывал перед приезжим двери помещичьих домов, ведь даже в самых захолустных городках владение французским языком считалось принадлежностью к «высшему свету», и его изучение являлось обязательным.

Качество преподавания, конечно, было весьма низким. Так, в мемуарах русского ученого-ботаника, философа, писателя А.Т. Болотова можно прочитать как проходило его обучение французскому языку в 1750-1752 гг. в доме генерал-аншефа Я.В. Маслова в Петербурге [13]. Учителем был француз Лапис. Он был довольно образованным человеком, но совершенно не умел учить детей. Русского языка он не знал. Все обучение заключалось в том, что ученики переписывали статьи из толкового словаря, изданного Французской академией наук. Дети плохо понимали, о чем идет речь в этих статьях, а учитель не стремился помочь им какими-то пояснениями. Переписанные статьи механически заучивались наизусть без понимания смысла. Конечно, такой способ обучения не приносил детям ни малейшей пользы. Как пишет мемуарист, «бездельники-французы не учат, а мучат наших детей сущими пустяками, стремясь чем-нибудь да провесть время» [13].

Работали французы-эмигранты и преподавателями в учреждениях образования - гимназиях, школах, частных пансионах, университетах. Профессиональная подготовка и квалификация этих сотрудников была гораздо выше, чем домашних учителей, ведь принимали их на должность лишь при наличии диплома и рекомендаций [12, с. 33]. Преподаватели французы занимались и научной, исследовательской деятельностью.

В университетах французский язык начинал играть все более значимую роль. По-французски читались, в первую очередь, курс французского языка и литературы, однако часто также и такие предметы, как история и география. С каждым годом правления Елизаветы Петровны все ощутимее было влияние французской литературы и искусства на мировоззрение российского высшего общества.

И все же при Елизавете эпоха Российской галломании, франкофонии лишь зарождалась, набирала обороты, наибольшую значимость и развитие это явление получило уже в эпоху Екатерины II, когда французский язык стал доминирующим в дворянской среде. Французский язык в то время стал языком международного общения, а Париж - столицей европейской политики. Сама 
императрица переписывалась с выдающимися французскими философами (Вольтер, Дидро и др.). А дети русских дворян сначала изучали французский, а затем свой родной язык. Для самопозиционирования в своей социальной среде, для приобщения к приоритетным на тот момент ценностям французского общества, владение французским языком признавалось обязательным атрибутом образованного, воспитанного человека [14, с. 624]. Галломания в Российской империи сохранилась и даже укрепилась после французской революции 1789 г. под влиянием многочисленных французских иммигрантов. Французский язык активно использовался не только в дипломатической переписке, но и в переписке чиновников в России. Только с середины XIX в. российские писатели, журналисты, государственные деятели стали все громче говорить о том, что франкомания губит русскую культуру и русский язык. Увлечение всем французским пошло на спад.

\section{ЛИТЕРАТУРА}

1. Писаренко, К.А. Елизавета Петровна / К.А. Писаренко. - М.: Молодая гвардия, 2014. - 462 с.

2. Бердников, Л. Веселовские / Л. Бердников // День и ночь. - 2010. - № 6 [Электронный ресурс]. - Режим доступа: https://magazines.gorky.media/ din/2010/6/veselovskie.html. - Дата доступа: 10.06.2020.

3. Энциклопедический словарь. Том VI. Венцано - Винона / издатели: Ф.А. Брокгауз, И.А. Ефрон. - С.-Петербург: Типо-Литография И.А. Ефрона, 1892. - С. 97-98.

4. Материалы для истории Императорской академии наук. - СПб: Тип. Императорской акад. наук, 1895. - Т. 7: (1744-1745). - 822 с.

5. Серов Д. О. Администрация Петра I / Дмитрий Серов. - 2-е изд. - М.: 0ГИ, 2008. - 288 с.

6. Соловьев, С.М. Сочинения: в 18 кн. / С.М. Соловьев; [отв. ред. И.Д. Ковальченко, С.С. Дмитриев]. - Кн. 10: История России с древнейших времен: Т. 19-20 / [коммент. С. М. Троицкого, И. В. Волковой]. - М.: Мысль, 1993. - 751 с.

7. Девятова, С.В. Развитие отечественной культуры при императрице Елизавете Петровне (1741-1761) / С.В. Девятова, В.И. Купцов // Человеческий капитал. - 2013. - № 4 (52). - С. 5-15.

8. Колобкова А.А. К вопросу об изучении французского языка в Российской империи в середине XVIII - начале XIX века // Ценности и смыслы. 2019. № 6 (64). С. 118-130.

9. Загрязкина, Т.Ю. Следы Франции в России / Т.Ю. Загрязкина // Вестник Московского университета. Сер. 19. Лингвистика и межкультурная коммуникация. -2009 . № 3. - С. 29-42.

10. Энциклопедический словарь. Т. 39а: Шенье - Шуйский монастырь / издатели: Ф.А. Брокгауз, И.А. Ефрон. - С.-Петербург: Типо-Литография И.А. Ефрона, 1903. - С. 537-538.

11. Валишевский, К.Ф. Вокруг трона / К. Валишевский. - М.: Рипол классик, 2005. - 384 с.

12. Загрязкина, Т.Ю. Следы Франции в России / Т.Ю. Загрязкина // Вестник Московского университета. Сер. 19. Лингвистика и межкультурная коммуникация. - 2009. - № 4. - С. 32-45.

13. Болотов, А.Т. Жизнь и приключения А. Т. Болотова, описанные им самим для своих потомков [Электронный ресурс]. - Режим доступа: http://az.lib.ru/b/ bolotow_a_t/text_0080.shtml. - Дата доступа: 10.06.2020.

14. Колобкова А.А. Российское национальное самосознание: обращение к образам прошлой педагогической реальности России XVIII-XIX веков, аспекты ретро инноваций в преподавании французского языка // Педагогический журнал. 2019. Т. 9. № 4-2. С. 623-631.

(c) Колобкова Анастасия Анатольевна (akolobkova@yandex.ru).

Журнал «Современная наука: актуальные проблемы теории и практики» 